\title{
Large variability of proanthocyanidin content and composition in sainfoin (onobrychis viciifolia)
}

Article

Accepted Version

Malisch, C. S., Luescher, A., Baert, N., Engstrom, M. T., Studer, B., Fryganas, C., Suter, D., Mueller-Harvey, I. and Salminen, J.-P. (2015) Large variability of proanthocyanidin content and composition in sainfoin (onobrychis viciifolia). Journal of Agricultural and Food Chemistry, 63 (47). pp. 10234-10242. ISSN 1520-5118 doi:

https://doi.org/10.1021/acs.jafc.5b04946 Available at https://centaur.reading.ac.uk/46386/

It is advisable to refer to the publisher's version if you intend to cite from the work. See Guidance on citing.

To link to this article DOI: http://dx.doi.org/10.1021/acs.jafc.5b04946

Publisher: American Chemical Society

All outputs in CentAUR are protected by Intellectual Property Rights law, including copyright law. Copyright and IPR is retained by the creators or other copyright holders. Terms and conditions for use of this material are defined in the End User Agreement. 


\section{CentAUR}

Central Archive at the University of Reading

Reading's research outputs online 


\section{Large variability of proanthocyanidin content and composition in sainfoin (Onobrychis viciifolia)}

Carsten Stefan Malisch, Andreas Lüscher, Nicolas Baert, Marica Therese Engström, Bruno

Studer, Christos Fryganas, Daniel Suter, Irene Mueller-Harvey, and Juha-Pekka Salminen

J. Agric. Food Chem., Just Accepted Manuscript • DOI: 10.1021/acs.jafc.5b04946 • Publication Date (Web): 09 Nov 2015

Downloaded from http://pubs.acs.org on November 10, 2015

\section{Just Accepted}

"Just Accepted" manuscripts have been peer-reviewed and accepted for publication. They are posted online prior to technical editing, formatting for publication and author proofing. The American Chemical Society provides "Just Accepted" as a free service to the research community to expedite the dissemination of scientific material as soon as possible after acceptance. "Just Accepted" manuscripts appear in full in PDF format accompanied by an HTML abstract. "Just Accepted" manuscripts have been fully peer reviewed, but should not be considered the official version of record. They are accessible to all readers and citable by the Digital Object Identifier (DOI $\left.{ }^{\circ}\right)$. "Just Accepted" is an optional service offered to authors. Therefore, the "Just Accepted" Web site may not include all articles that will be published in the journal. After a manuscript is technically edited and formatted, it will be removed from the "Just Accepted" Web site and published as an ASAP article. Note that technical editing may introduce minor changes to the manuscript text and/or graphics which could affect content, and all legal disclaimers and ethical guidelines that apply to the journal pertain. ACS cannot be held responsible for errors or consequences arising from the use of information contained in these "Just Accepted" manuscripts. 


\section{Large variability of proanthocyanidin content and composition in sainfoin}

\section{(Onobrychis viciifolia)}

Carsten S. Malisch ${ }^{\dagger, \#}$, Andreas Lüscher ${ }^{*}, \dagger$, Nicolas Baert $^{\S}$, Marica T. Engström ${ }^{\S}$, Bruno Studer ${ }^{\#}$, Christos Fryganas ${ }^{\ddagger}$, Daniel Suter ${ }^{\dagger}$, Irene Mueller-Harvey , Juha-Pekka Salminen $^{\S}$

$\dagger$ Forage Production and Grassland Systems, Institute for Sustainability Sciences ISS, Agroscope, Reckenholzstrasse 191, CH-8046 Zurich

\# Forage Crop Genetics, Institute of Agricultural Sciences, ETH Zurich, CH-8092 Zurich

$\S$ Laboratory of Organic Chemistry and Chemical Biology, Department of Chemistry, University of Turku, FI-20500 Turku

† Chemistry and Biochemistry Laboratory, School of Agriculture, Policy and Development, University of Reading, UK-Reading RG6 6AT 


\section{Abstract}

2 Proanthocyanidins (PAs) in sainfoin (Onobrychis viciifolia Scop.) are of interest to ameliorate

3 the sustainability of livestock production. However, sainfoin forage yield and PA

4 concentrations, as well as their composition, require optimization. Individual plants of 27

5 sainfoin accessions from four continents were analyzed with LC-ESI-QqQ-MS/MS for PA

6 concentrations and simple phenolic compounds. Large variability existed in PA concentrations

7 (23.0-47.5 $\mathrm{mg} \mathrm{g}^{-1}$ leaf dry matter (DM)), share of prodelphinidins (79-96\%), and mean degree

8 of polymerization (11-14) among, but also within, accessions. PAs were mainly located in

9 leaves $\left(26.8 \mathrm{mg} \mathrm{g}^{-1} \mathrm{DM}\right)$, while stems had less PAs $\left(7.8 \mathrm{mg} \mathrm{g}^{-1} \mathrm{DM}\right)$. Overall, high yielding

10 plants had lower PA leaf concentrations $\left(R^{2}=0.16, P<0.001\right)$ and fewer leaves $\left(R^{2}=0.66\right.$,

$11 P<0.001)$. However, the results show that these two trade-offs between yield and bioactive PAs

12 can be overcome.

\section{Keywords}

14 Condensed tannins, LC-ESI-QqQ-MS/MS, Yield, Breeding, Polyphenols 


\section{Introduction}

Sainfoin (Onobrychis viciifolia Scop.) is a traditional forage legume that was an important forage source as early as the mid $-16^{\text {th }}$ century. ${ }^{1}$ While it was a very important forage crop for a long time, it lost importance in the second half of the $20^{\text {th }}$ century, due to other forages exhibiting higher yields and better tolerance towards frequent cutting. ${ }^{2}$ Nowadays, as livestock farming has attracted public debate, due to, among other reasons: (i) contributions to climate change, both directly (greenhouse gas emissions) and indirectly (deforestation), and (ii) sources of nutrient pollution for water bodies, resulting both from feed and livestock production, sainfoin has benefited from a renewed interest (www.legumeplus.eu). ${ }^{3}$ Because of various beneficial properties, mostly linked to the presence of proanthocyanidins (PAs) (syn. condensed tannins) and the ability to fix nitrogen directly from the air (reviewed by Lüscher et al, 2014 and Wang et al, 2015), ${ }^{4,5}$ sainfoin is potentially considered a partial solution. The beneficial properties include an ability to grow on marginal soils without mineral nitrogen fertilizer, thus reducing environmental pollution and competition with food production; lower nitrous oxide emissions due to a shift of the nitrogen excretion pathway from urine to a more stable form in feces; and there are also some indications that PAs may have the potential to reduce methane emissions. Additional benefits include lower burdens of parasitic gastrointestinal nematodes and bloat prevention, thereby increasing animal health and welfare. ${ }^{6,7}$ Furthermore, sainfoin has a good forage quality with higher crude protein and total sugar contents than birdsfoot trefoil (Lotus corniculatus) and chicory (Cichorium intybus). ${ }^{8}$

Individual PA compounds in a plant can be constructed of either procyanidin (PC) or prodelphinidin (PD) sub-units, but it is quite common to find oligomeric (2-10 sub-units) and polymeric PAs (>10 sub-units) that contain both PC and PD units. In addition, individual plants synthesize a mixture of tens to hundreds of different oligomers and polymers. Among these types of PC/PD mixtures of oligo- and polymers, PD-rich PAs have generally shown higher 
anti-parasitic activity than PC-rich PAs,,${ }^{9,10}$ and PAs rich in polymers have been shown to improve anti-parasitic effects and the potential for reducing methane emission. ${ }^{11}$ This may be related to the fact that PAs with higher molecular weights (i.e. polymer size) are better able to interact with macromolecules, ${ }^{12,13}$ although this may not be the sole factor. However, higher PC share on the other hand, seems to enhance protein-protection, which is important for ruminant nutrition and also for sustainable livestock production. The exact reasons for this remain unclear, but PDs are expected to have a higher protein binding affinity than PCs based on their ability to form more hydrogen bonds. This would make tannin-protein complexes consisting of PD-rich tannins more difficult to dissociate in the digestive tract and thus lead to higher fecal nitrogen losses in ruminants. ${ }^{7}$ Therefore, farmers will need sainfoin varieties with both a PA composition that is optimized for animal health and for nutrition, and with sufficient concentrations of these optimized PAs. ${ }^{9,10}$ Interestingly, anthelmintic properties may also be enhanced by monomeric flavonoids, ${ }^{14,15}$ which are very common in many plants. As recent findings have determined that the average composition of PAs is, at least in part, heritable, ${ }^{16,17}$ the major remaining obstacle is the variability in PA concentration, which is required for optimization. However, until recently, screening of large numbers of individual plants simultaneously for PA concentrations and their composition was not feasible, which prohibited detailed characterization of this variability. Hence, with the exception of one accession, the differences in PA concentrations among individual plants have never been established. ${ }^{18}$ The previous limitations have since been overcome by a new method for UPLC-MS/MS analysis of extractable PAs, which allows high-throughput rates for the measurement of PA composition, such as the mean degree of polymerization $(\mathrm{mDP})$ and $\mathrm{PC} / \mathrm{PD}$ ratios, allowing for large screenings of individual plants for their PA concentration and composition. ${ }^{19}$

As PA-based bioactivity of sainfoin is of interest for increasing the sustainability of livestock production systems, we evaluated the existing variability of PA properties (PA concentration 
and composition) and of agronomic properties (yield and leaf share) in sainfoin. Special emphasis was placed (i) on variability in PA properties at different levels, such as among accessions, among individual plants within accessions and among plant organs within individual plants and (ii) on the correlation between the PA properties of a plant and its yield. Our findings will be of substantial value for the optimization of sainfoin as a bioactive forage, by establishing that the required variability in PA concentration and composition is available and that the concomitant improvement of yields and PA properties in sainfoin is possible.

\section{Materials and Methods}

\section{Chemicals and Reagents}

Technical grade acetone for extraction was purchased from VWR (Haasrode, Belgium). Formic acid $(\mathrm{HCOOH})$ and LC-MS Chromasolv acetonitrile for the UHPLC-ESI-QqQ-MS were obtained from Sigma-Aldrich (Seelze, Germany) and catechin for the catechin stock solution was acquired from Sigma-Aldrich (St. Louis, MO, USA). Kaempferol-3-O-rutinoside, myricitrin, caffeoylquinic acid, arbutin, quercetin- $O$-rutinoside for the calibration curves, as well as kaempferol-7-O-glucoside, kaempferol-7- $O$-neohesperoside, kaempferol-3-Oglucoside, hyperoside and quercetin glucopyranoside for the stock solutions were obtained from Extrasynthese (Genay, France). Digalloylglucose (98\% purity, as determined by UPLC-DAD) for the calibration of galloylated compounds was purified by J.-P. Salminen (University of Turku, Turku, Finland) from a Betula pubescens leaf extract by a combination of Sephadex LH20 gel chromatography and semipreparative HPLC. Water was purified with a Millipore Synergy water purification system from Merck KGaA (Darmstadt, Germany). Sephadex LH20 was obtained from GE Healthcare (GE Healthcare, Uppsala, Sweden). 
87

88

89

90

91

92

93

94

95

96

97

98

99

100

101

102

103

104

105

106

107

108

109

\section{Site description}

Plant material was harvested from a field experiment in Rümlang (47 $44^{\prime} \mathrm{N} 8^{\circ} 53^{\prime} \mathrm{E}$, $482 \mathrm{~m}$ a.s.1), near Zurich, Switzerland. The soil is a calcic cambisol of at least $0.75 \mathrm{~m}$ depth and ranges from loam to clay loam. The volume of the soil skeleton was measured at $5-10 \%$ and the $\mathrm{pH}$ was 7.1. Except where otherwise noted, all data were generated under the following environmental conditions: cumulative precipitation from the sowing of the experiment (June, $1^{\text {st }}$ ) to the harvest of the samples (September, 24 ${ }^{\text {th }}$ ) was $559 \mathrm{~mm}$ (annual cumulative precipitation: $1165 \mathrm{~mm}$ ) at the Agroscope research station, which is $1 \mathrm{~km}$ from the field site (shortest, direct route). The average temperature over the same time frame was $17.7^{\circ} \mathrm{C}$ (average annual temperature: $\left.9.8^{\circ} \mathrm{C}\right)$.

\section{Experimental design}

In a common garden experiment, seeds of 27 sainfoin accessions (Table S1) were sown in 8 replicates in a randomized complete block design. We aimed to cover a large range of variability, and thus the accessions were selected according to their status of cultivation, covering a range from wild accessions to fully registered cultivars, as well as according to their geographic origin, covering 12 different countries from four different continents. Each accession was sown in a row with $0.5 \mathrm{~m}$ distance between accessions, and out of germinated seedlings, healthy individuals that were $0.25 \mathrm{~m}$ apart from each other (within rows) were selected for further examination, and all others were removed. Each row consisted of 13 plants, from which 9 were experimental plants: the two plants on each end were eliminated to decrease margin effects. The design, thus, added up to a total of 1944 experimental plants ( 27 accessions x 8 replicates (i.e. blocks) x 9 individuals), with a subset of the 9 individuals per block and accession being used for the various analyses described below. 


\section{Sampling}

111 For the chemical analysis, from each of the 27 accessions, at least 12 plants were selected according to size (large, medium and small size, from a subset of 4 blocks), to determine the possible trade-off between plant size and PA concentration, and to cover the whole range of variability within and among the accessions. Altogether, polyphenol extracts from a subset of 364 individual plants from all accessions was analyzed by UPLC-ESI-QqQ-MS/MS. Per plant, five whole leaves (leaflets including petiole and rachis) of a comparative developmental stage (intermediate age) were taken from each plant. Additionally, young (freshly unfolded) and old leaves (Figure S1), as well as stems, were harvested simultaneously from a subset of seven accessions to study the variability of PA among plant organs. Sampling was conducted in the morning of a cool, cloudy autumn day, to prevent evapotranspiration and biological degradation. Immediately after sampling, samples were cooled on dry ice and within an hour stored in a $-70{ }^{\circ} \mathrm{C}$ freezer. Prior to grinding and extraction, samples were taken out of the freezer, immediately dipped in liquid nitrogen and loaded into a precooled Freeze Drying Plant

125 For agronomical measurements, all 1944 experimental plants, including the subset used for chemical analysis, were oven dried at $40{ }^{\circ} \mathrm{C}$, with high air throughput rates, to constant weight.

127 In addition to dry matter, the leaf ratio (leaf dry mass to plant total dry mass) was determined 128 for 545 plants, which included 102 large and medium plants used for chemical analysis.

\section{Extraction and sample preparation}

130 After freeze drying, chemical samples were ground using a MM 400 ball mill (Retsch

131 Technology $\mathrm{GmbH}$, Haan, Germany) in $25 \mathrm{~mL}$ tungsten carbide containers with four tungsten 132 carbide balls ( $7 \mathrm{~mm}$ diameter). Plant material (20 $\mathrm{mg}$ ) was weighed into $2 \mathrm{~mL}$ Eppendorf tubes 133 and stored at $-20{ }^{\circ} \mathrm{C}$. For extraction, $1.4 \mathrm{~mL}$ of acetone/ $\mathrm{H}_{2} \mathrm{O}(80: 20$, v/v) was added into the 
134 Eppendorf tubes, which were then shaken for 15 minutes, and the plant/solvent mixture was

135 allowed to macerate in a fridge overnight to enhance the extraction efficiency of especially 136 large PAs. ${ }^{20,21}$ The tubes were then shaken in a planar shaker for 3 hours before centrifuging 137 at $12,000 \mathrm{~g}$ and decanting the solvent. The solvent samples were concentrated for 138 approximately 2 hours in an Eppendorf concentrator plus (Eppendorf AG, Hamburg, Germany) 139 to remove the acetone, while the plant residues were extracted with a new $1.4 \mathrm{~mL}$ of acetone/ $140 \mathrm{H}_{2} \mathrm{O}(80: 20, \mathrm{v} / \mathrm{v})$ for an additional 3 hours. The two extracts were then combined and 141 concentrated into the water phase. Subsequently, the extracts were frozen and freeze dried with

142 a Christ Alpha 2-4 (B. Braun Biotech International, Melsungen, Germany) overnight and stored 143 at $-20{ }^{\circ} \mathrm{C}$. Prior to injection in the UPLC-MS/MS, samples were dissolved in $1 \mathrm{~mL}$ of ultrapure 144 water, shaken for 10 minutes, filtered with $0.2 \mu \mathrm{m}$ PTFE syringe filters (VWR International, 145 Radnor, PA, USA) and diluted 4-fold with ultrapure water.

\section{Treatment of extracts with Sephadex LH-20}

147 For identification of the main monomeric phenolic compounds, equal plant subsamples of 200 $148 \mathrm{mg}$ were taken from 50 randomly selected samples, to obtain a $10 \mathrm{~g}$ pooled sample. The pooled 149 sample was then extracted according to the protocol above, but solvent quantities were adjusted 150 according to the increased plant biomass. Of the freeze-dried crude extract, $2 \mathrm{~g}$ were dissolved 151 in a small quantity of ultrapure water and loaded onto a Sephadex LH-20 column, which had 152 been equilibrated with $100 \%$ water. Solvents were pumped with a flow rate of $5 \mathrm{~mL} / \mathrm{min}$ with 153 the following gradient: water fraction $\left(100 \% \mathrm{H}_{2} \mathrm{O}, 1000 \mathrm{~mL}\right), \mathrm{MeOH}: \mathrm{H}_{2} \mathrm{O}(50: 50$, v/v; $154500 \mathrm{~mL})$, acetone: $\mathrm{H}_{2} \mathrm{O}(20: 80$, v/v; $500 \mathrm{~mL})$, acetone: $\mathrm{H}_{2} \mathrm{O}(40: 60$, v/v; $500 \mathrm{~mL})$, acetone: $\mathrm{H}_{2} \mathrm{O}$ 155 (60:40, v/v; $500 \mathrm{~mL})$ and acetone: $\mathrm{H}_{2} \mathrm{O}(80: 20, \mathrm{v} / \mathrm{v} ; 500 \mathrm{~mL})$. The fractions were collected 156 separately, organic solvents removed with a rotary evaporator, and the remaining aqueous 157 extracts frozen and lyophilized. 
158

159

160

161

162

163

164

165

166

167

168

169

170

171

172

173

174

175

176

177

178

179

180

181

\section{UPLC-MS/MS analysis}

The UPLC-MS/MS analysis was conducted according to Engström et al. ${ }^{19}$ on the Acquity UPLC system (Waters Corp., Milford, MA, USA), interfaced to a Xevo TQ triple-quadrupole mass spectrometer with electrospray ionization (ESI) (Waters Corp., Milford, MA, USA). In brief, the UPLC system was equipped with an autosampler, a binary solvent manager, a 100 $\mathrm{mm} \times 2.1 \mathrm{~mm}$ i.d., $1.7 \mu \mathrm{m}$, an Acquity UPLC BEH Phenyl column (Waters Corp., Wexford, Ireland), and a diode array detector. The flow rate was set to $0.5 \mathrm{~mL} / \mathrm{min}$, and the mobile phase consisted of two solvents: acetonitrile (A) and $0.1 \%$ aqueous formic acid (B) with the following gradient profile: $0-0.5 \mathrm{~min}, 0.1 \% \mathrm{~A}$ in $\mathrm{B}$ (isocratic); $0.5-5.0 \mathrm{~min}, 0.1-30 \% \mathrm{~A}$ in $\mathrm{B}$ (linear gradient); 5.0-6.0 $\mathrm{min}, 30-35 \% \mathrm{~A}$ in $\mathrm{B}$ (linear gradient); 6.0-9.5 min, column wash and stabilization. Data collection of both UV and MS occurred continuously from 0 to 6 min. Negative ESI mode was used, with ESI conditions as follows: capillary voltage, $2.4 \mathrm{kV}$; desolvation temperature, $650{ }^{\circ} \mathrm{C}$; source temperature, $150{ }^{\circ} \mathrm{C}$; desolvation and cone gas $\left(\mathrm{N}_{2}\right)$, 1000 and $100 \mathrm{~L} / \mathrm{h}$, respectively; and argon as collision gas.

\section{Standards and method performance}

Before each run, a flavonoid mix stock solution containing $4 \mu \mathrm{g} \mathrm{mL} \mathrm{L}^{-1}$ each of kaempferol-7-Oglucoside, kaempferol-7- $O$-neohesperoside, kaempferol-3-O-glucoside, quercetin-3-Ogalactoside and quercetin-3-O-glucoside, in a mixture of acetonitrile / $0.1 \%$ aqueous formic acid $(1: 4 \mathrm{v} / \mathrm{v})$ was injected twice to assess the performance of the system (stability of the UPLC retention times, and $\mathrm{m} / \mathrm{z}$ values of the MS detector). Furthermore, a catechin stock solution, containing $1 \mu \mathrm{g} \mathrm{mL}^{-1}$ of catechin in a mixture of acetonitrile / $0.1 \%$ aqueous formic acid (1:4 $\mathrm{v} / \mathrm{v}$ ) was injected five times every ten samples, to account for possible changes in the quantitative performance of the MS/MS system for polyphenols throughout the 110 minutes that was required for each analysis set of 10 samples. Quantitative results were corrected for 
182

183

184

185

186

187

188

189

190

191

192

193

194

195

196

197

198

199

200

201

202

203

204

205

206

possible fluctuations in the system's quantitative performance within each analysis set, as well as among different sets. Replicate analyses (the same sample injected 10 times) were tested for quantitative results, and the relative standard deviation (RSD) was $\pm 2.8 \%$ (range $\pm 0.8-6.5 \%$, Table 1) for all compounds that were analyzed quantitatively.

\section{Calibration curves}

In addition to the quantitative measurements of PA concentration and the determination of its composition ( $\mathrm{PC} / \mathrm{PD}$ ratio, $\mathrm{mDP}$, and largest mean degree of polymerization maxmDP), we performed a qualitative analysis of 24 individual phenolic compounds, six of which were also quantified and thus required calibration curves for quantification (Table 1). Identification of compounds is described in the supporting information. Dilution series from stock solutions of $40 \mu \mathrm{g} \mathrm{mL}^{-1}$ were prepared for calibration of kaempferol-3-O-rutinoside, myricitrin, chlorogenic acid, and rutin and were diluted with $\mathrm{H}_{2} \mathrm{O}$. The dilution range was from $40 \mu \mathrm{g} \mathrm{mL}^{-1}$ to 0.3125 $\mu \mathrm{g} \mathrm{mL} L^{-1}$. The arbutin dilution series from a stock solution of $200 \mu \mathrm{g} \mathrm{mL}^{-1}$ diluted in $\mathrm{H}_{2} \mathrm{O}$ ranged from $200 \mu \mathrm{g} \mathrm{mL}^{-1}$ to $20 \mu \mathrm{g} \mathrm{mL} \mathrm{m}^{-1}$, and the dilution series of digalloylglucose was prepared from a stock solution of $10 \mu \mathrm{g} \mathrm{mL}^{-1}$ and ranged from $10 \mu \mathrm{g} \mathrm{mL}^{-1}$ to $0.375 \mu \mathrm{g} \mathrm{mL} L^{-1}$ and diluted with $\mathrm{H}_{2} \mathrm{O}$. Calibration curves for PC and PD concentrations were produced as described in Engstroem et al. (2014) from purified PA stock solutions $\left(1.0 \mu \mathrm{g} \mathrm{mL}^{-1}\right)$ of a PC-rich sample (Salix caprea leaves: 95\% pure, as determined by thiolysis) and a PD-rich sample (Trifolium repens flowers: $98 \%$ pure, as determined by thiolysis), ${ }^{19}$ respectively, by diluting with acetonitrile $/ \mathrm{H}_{2} \mathrm{O}(20: 80, \mathrm{v} / \mathrm{v})$. The dilution range was from $1.0 \mu \mathrm{g} \mathrm{mL}^{-1}$ to $0.01 \mu \mathrm{g} \mathrm{mL}^{-1}$. Calibration curves were used to determine the linear range for quantification. The mDP was determined according to Engström et al. $(2014)^{19}$ by calculating the ratio of terminal and extension units for both PCs and PDs (eqn S1). As larger PAs tend to elute later, the maxmDP was calculated by utilizing the same method as for $\mathrm{mDP}$, but only integrated the terminal units and extension units from a retention time window from 3.70 to 5.50 minutes, which enabled a 
207 208 209

strong enough signal for the terminal and extension units of the larger PAs. Thus, the maxmDP is not the largest polymer size found in the analyzed sample per se, but it shows reliably the mean degree of polymerization for the largest PA polymers that elute in that given retention time window (Figure S2). The maxmDP could also have been calculated from a later retention time window, but this approach would generate less reliable data from samples with low amounts of such PAs.

\section{Statistical Analysis}

The primary response variables analyzed were plant weight, leaf ratio, PA concentration, mDP, and the share of prodelphinidins. Because accessions were selected for high variability both in their geographic origin and their cultivation status (i.e. cultivars, wild accessions), both criteria were initially tested for their impact on the response variables. It turned out that the geographic origin of an accession was of minor importance in explaining variation in the response variables. Therefore, regarding the following analyses, accessions were grouped only for their cultivation status without consideration of the origin. The 27 accessions were assigned to one of three groups of cultivation status. Cultivar/cultivated (hereafter referred to as "cultivars") were accessions that have been cultured substantially and were, in most cases, even registered as cultivars. Ecotype/landrace (referred to as "landraces") were "adapted to a specific region or location, such as a farm", i.e. a very small scale, with landrace adaptation being driven by human intervention and ecotype adaptation driven by natural selection pressures. ${ }^{22}$ Wild/unknown (referred to as "wild") were either wild accessions or accessions where the cultivation status was not well established, which hints at a very low level of cultivation.

The effects of the cultivation status and the accession on the response variables were analyzed with linear mixed regression. ${ }^{23}$ With $y$ being one of the response variables (plant weight, etc., see above), the model was: 
232 with $y_{i j k m}$ being the response of the $i^{\text {th }}$ plant of cultivation status $j$ and accession $k$ in block $m$. 233 The fixed parameter $\alpha$ estimates the mean response of the cultivation status $j$. To consider the 234 variation of accessions within their status, $b$ was modeled as a random parameter with $b \sim N(0$, $\left.235 \sigma_{b}^{2}\right)$. Likewise, block was modeled as a random parameter with $g \sim N\left(0, \sigma_{g}^{2}\right)$. The error $e_{i}$ was 236 assumed to be normally distributed with zero mean and variance $\sigma^{2}$. The model contrasts were 237 used to infer differences among groups of the cultivation status.

238 Variability within accessions was evaluated by analysis of the population standard deviations 239 of the 27 accessions. To this aim, a modified version of eqn 1 was used:

241 Here, the fixed parameter $\beta$ estimates the mean response of accession $k$, with the random variable block, as defined above. The variance parameter is $\operatorname{Var}\left(e_{k i}\right)=\sigma^{2} \delta_{k}^{2}$, with $\delta$ being a ratio that represents $k$ variances, one for each accession. Inference of the average variances of the three groups $j$ of the cultivation status were derived from a model similar to eqn 2 , but using 245 only three variance estimates, i.e. with $\operatorname{Var}\left(e_{j i}\right)=\sigma^{2} \delta_{j}^{2}$. To achieve normality and 246 homoscedasticity of the error variance, the plant weight was $\log$ transformed in eqs $1 \& 2$; and 247 the PD share was logit transformed, because its values were restricted between zero and one. ${ }^{23}$ $P$-values of all correlations were calculated utilizing the Pearson's product moment correlation coefficient, while checking the data for outliers. All analyses were performed using the statistical software $\mathrm{R},{ }^{24}$ with Figure 2 being generated using the R-package 'multcompView' ${ }^{25}$ 


\section{Results and Discussion}

\section{Variability among accessions}

253 Over all 27 accessions, the concentration of PAs in leaves varied by a factor of 2, with the 254 accession average ranging from $23.0 \mathrm{mg} \mathrm{g}^{-1} \mathrm{DM}$ to $47.5 \mathrm{mg} \mathrm{g}^{-1} \mathrm{DM}$ (Figure 1). The other PA 255 properties varied less: the accession means of PD share in leaves ranged from $79 \%$ to $96 \%$ of 256 the PAs and mDP ranged from 11 to 14 . The maxmDP ranged from 23 to 32 flavan-3-ol units 257 (results not shown, as maxmDP was strongly related to $\left.\mathrm{mDP}\left(\mathrm{R}^{2}: 0.75, P<0.001\right)\right)$. The largest 258 variability occurred in the forage yield, where the smallest accession had, on average, $0.2 \mathrm{~g} \mathrm{DM}$ 259 plant $^{-1}$, whereas the largest accession yielded an average $20.3 \mathrm{~g} \mathrm{DM} \mathrm{plant}^{-1}$ (Figure 1). The 260 accessions had a highly significant impact on all four parameters described above $(P<0.001)$.

261 The cultivation status of the accessions contributed significantly to the overall variability 262 among accessions described above. With their group mean of $32.7 \mathrm{mg} \mathrm{g}^{-1} \mathrm{DM}$, wild accessions 263 had higher $(P<0.001)$ leaf PA concentrations than cultivars $\left(26.5 \mathrm{mg} \mathrm{g}^{-1} \mathrm{DM}\right)$ and landraces 264 (25.6 $\left.\mathrm{mg} \mathrm{g}^{-1} \mathrm{DM}\right)$ (Figure 1). In contrast, group means for yield were clearly higher $(P<0.001)$ 265 for cultivars (9.7 $\mathrm{g} \mathrm{DM}$ plant $\left.^{-1}\right)$ and landraces (8.9 $\left.\mathrm{g} \mathrm{DM} \mathrm{plant}^{-1}\right)$ than for wild accessions (3.0 $266 \mathrm{~g} \mathrm{DM}_{\text {plant }}{ }^{-1}$ ). These effects of cultivation status may be explained by the fact that until now, 267 breeding efforts have been aimed at improving the agronomic performance of sainfoin, as is 268 stated for the breeding of the cultivars Nova and Melrose, bred in Canada. ${ }^{26}$ Improving yields 269 is a major aim of breeding for all crops and has also been successful during recent decades for 270 forage crops. ${ }^{27}$ In addition, visual scoring of yield is fast and easy to conduct with a limited 271 amount of labor. This explains why PAs were not a breeding target in the past. However, a 272 recently developed, novel technique has made it possible now to scan large numbers of plants 273 for PAs and thus to exploit the beneficial impacts PAs have on animal health and the 274 environment. ${ }^{19}$ 
275 While low PA concentrations in cultivars may be insufficient for the bioactivity of sainfoin, we 276 also found that forage yield was of substantial importance for producing high amounts of PAs 277 per plant. This is because the difference between the forage yields in cultivars as compared to 278 those in wild accessions was, on average, 76\%, whereas the respective difference in PA 279 concentration was, on average, only $20 \%$ (Figure 1). Consequently, when calculating the 280 amount of PAs per plant (eqn S2), as determined by the biomass and PA concentration exhibited 281 in Figure 1, cultivars achieved on average $332 \mathrm{mg} \mathrm{plant}^{-1}$ (median: $298 \mathrm{mg}$ plant $^{-1}$ ), which was 282 higher compared to wild accessions $(P<0.01)$ with $263 \mathrm{mg} \mathrm{plant}^{-1}$ (median: $\left.177 \mathrm{mg} \mathrm{plant}^{-1}\right)$. 283 Landraces were not significantly different from either cultivars or wild accessions with $256 \mathrm{mg}$ 284 plant $^{-1}$ (median: $234 \mathrm{mg} \mathrm{plant}^{-1}$ ).

\section{Variability within accessions}

286

The variability among individual plants within accessions was huge. For example, the standard deviation of PA concentration in leaves of WKT10 was $10.6 \mathrm{mg} \mathrm{g}^{-1} \mathrm{DM}$ (Figure 1), meaning that approximately $1 / 3$ of the plants had PA leaf concentrations of above $58.1 \mathrm{mg} \mathrm{g}^{-1} \mathrm{DM}$ (mean PA of WKT10 + 1 standard deviation) or below $36.9 \mathrm{mg} \mathrm{g}^{-1}$ DM (mean - 1 standard deviation). This range in PA within accessions was comparable to the range among the accession means: the greatest mean PA value of all 27 accessions was $47.5 \mathrm{mg} \mathrm{PA} \mathrm{g}^{-1}$ DM in WKT10, while the smallest PA value was $23.0 \mathrm{mg} \mathrm{g}^{-1} \mathrm{DM}$ in Wiedlisbach. The largest variability within accession was found with respect to plant yields. There, the standard deviation for CPI 63820 identified one third of the plants to be either above $21.6 \mathrm{~g} \mathrm{DM}_{\text {plant }}{ }^{-1}$ or below $0.6 \mathrm{~g} \mathrm{DM}$ plant ${ }^{-1}$, compared to the range in accession means of $20.3 \mathrm{~g} \mathrm{DM}_{\text {plant }}^{-1}$ to $0.3 \mathrm{~g} \mathrm{DM}$ plant $^{-1}$. Figure 1 further shows that the variabilities within the accessions (standard deviation) for $\mathrm{mDP}$ and $\mathrm{PD}$ share were slightly smaller than that of PA leaf concentration. 
298 The cultivation status had a distinct effect on the variability exhibited within accessions: with 299 a group mean standard deviation of $7.5 \mathrm{mg} \mathrm{g}^{-1} \mathrm{DM}$ for PA leaf concentration, wild accessions 300 had, on average, a greater $(P<0.001)$ standard deviation than cultivars $\left(5.9 \mathrm{mg} \mathrm{g}^{-1} \mathrm{DM}\right)$ and 301 landraces $\left(5.3 \mathrm{mg} \mathrm{g}^{-1} \mathrm{DM}\right)$. For plant weight, the average standard deviation in wild accessions $302\left(2.9 \mathrm{~g} \mathrm{DM}\right.$ plant $\left.{ }^{-1}\right)$ was also larger $(P<0.001)$ than in both cultivars $\left(2.0 \mathrm{~g} \mathrm{DM} \mathrm{plant}^{-1}\right)$ and 303 landraces (1.9 $\mathrm{g} \mathrm{DM}$ plant $\left.^{-1}\right)$. This may be explained, at least for registered cultivars, by the fact 304 that uniformity is one of the criteria that cultivars have to fulfill for registration, according to 305 paragraph 6 of Council Directive 2002/53/EC of 13 June 2002 from the European Union. ${ }^{28}$ Still, the observed variability is invaluable for the optimization of sainfoin.

\section{Variability within the plant}

The mean leaf concentration of PAs (averaged over all three age classes of leaves) was $26.8 \mathrm{mg} \mathrm{g}^{-1} \mathrm{DM}$, and, thus was almost 3.5 times higher $(P<0.001)$ than the stem concentration of PAs, which was only $7.8 \mathrm{mg} \mathrm{g}^{-1} \mathrm{DM}$ (Figure 2). This is consistent with the literature, although the extent of the difference was more pronounced in our findings. ${ }^{29,30}$ The composition of the PAs in sainfoin leaves might also be better suited for anthelmintic effects and methane suppression: leaves had longer $(P<0.001)$ polymers (mDP: 13 , maxmDP: 28$)$ than stems $(\mathrm{mDP}$ : 5, maxmDP: 10), and a higher $(P<0.001)$ share of PDs $(89 \%)$ than stems $(60 \%)$. Furthermore, quercetin- $O$-rutinoside (rutin) and kaempferol- $O$-rutinoside (nicotiflorin) were also significantly higher $(P<0.001)$ in leaves than in stems. Leaves had, on average, concentrations of $5.9 \mathrm{mg} \mathrm{g}^{-1} \mathrm{DM}$ rutin and $0.7 \mathrm{mg} \mathrm{g}^{-1} \mathrm{DM}$ nicotiflorin, compared to stems with $1.4 \mathrm{mg} \mathrm{g}^{-1} \mathrm{DM}$ and $0.0 \mathrm{mg} \mathrm{g}^{-1} \mathrm{DM}$, respectively (Figure 2). Rutin has been shown to exhibit antioxidant and anti-inflammatory properties. ${ }^{31}$ Additionally, both rutin and nicotiflorin are also expected to enhance the anthelmintic of PAs. A study by Barrau (2005) $)^{14}$ found that in high concentrations, rutin resulted in $25 \%$ and nicotiflorin in $30 \%$ reduction of the larval migration of Haemonchus 
323

324

325

326

327

whether this effect was additive with the effect of PAs, or whether an interaction between PAs and the flavonoids occurred. The large differences in PAs found in stems and leaves demonstrate that the leaf share of a plant may be as, or even more, important for PA concentration and PA composition of the whole forage plant than the concentration and composition of PA in the leaves alone.

The three leaf age classes differed significantly in their PA properties, although the differences were clearly smaller than those observed between leaves and stems (Figure 2). Proanthocyanidins changed from an average concentration of $38.8 \mathrm{mg} \mathrm{g}^{-1} \mathrm{DM}$ in young leaves, to $20.9 \mathrm{mg} \mathrm{g}^{-1} \mathrm{DM}$ in old leaves $(P<0.001)$ (Figure 2$)$. The $\mathrm{mDP}$ increased $(P<0.001)$ from 12 to 14 , between young and old leaves, while the PD share changed $(P<0.05)$ from young $(90 \%)$ to old $(88 \%)$ leaves. Rutin decreased $(P<0.01)$ from $6.9 \mathrm{mg} \mathrm{g}^{-1} \mathrm{DM}$ to $5.3 \mathrm{mg} \mathrm{g}^{-1} \mathrm{DM}$, and nicotiflorin increased $(P<0.001)$ from $0.75 \mathrm{mg} \mathrm{g}^{-1} \mathrm{DM}$ to $0.99 \mathrm{mg} \mathrm{g}^{-1} \mathrm{DM}$ with aging of leaves. It has to be considered, however, that such concentration changes do not imply anything about the rates of PA synthesis. A graphical vector analysis (GVA), as proposed by Koricheva (1999), ${ }^{32}$ revealed that at first (young to intermediate aged leaves) the PAs showed predominantly a dilution effect, which indicates that the leaf biomass growth rates were higher than the PA synthesis rates. This reduced the concentration despite the fact that the amount of PA produced per leaf continued to increase. From intermediate-aged to old leaves, there was a shift towards a reduced synthesis rate of PAs (Figure 3), in which case even the PA amount decreased between intermediate and old leaves, although biomass of the leaves increased in the same time period. This indicates that either PAs were metabolized, or became insoluble and were, thus, not measured by our method, which only detects soluble PAs. This could, for example, happen when tannins are embedded into cell walls, as previously recorded for ellagitannins (syn. hydrolysable tannins). ${ }^{33}$ However, we did a follow up analysis on the extraction residues of 30 leaf samples (young, intermediate, and old leaves of 10 plants), which 
348 were tested for insoluble PAs with the modified HCl-butanol analysis. ${ }^{34}$ These analyses did not 349 find an increase in insoluble PAs with the aging of leaves (results not shown). Nevertheless, the 350 observed reduction in PA amounts agrees with another study by Lees, ${ }^{35}$ in which PAs were 351 located with light and electron microscopy in leaves of different developmental stages. These 352 authors found that although PAs were very abundant in young leaves, they seemed to disappear 353 with the aging of the leaf until the cells were almost entirely devoid of PAs.

\section{Trade-offs: the growth rate hypothesis}

355 To optimize sainfoin as a bioactive forage, it does not only need amelioration of PA properties 356 (concentration and composition) but also an improved biomass yield. Yield increase is crucial 357 in two respects: to produce higher amounts of PAs (at a given concentration of PA in that 358 biomass) and to make sainfoin more competitive compared to high yielding non-PA forage 359 species. However, there are potential trade-offs that may restrict the concomitant increase of sainfoin yield and PA properties. One potential trade-off between yield and PA properties is 361 based on the growth rate hypothesis (GRH) (also known as: resource availability 362 hypothesis). ${ }^{36,37}$ The GRH is based on the fact that plants only have limited resources, and each 363 resource can only be invested in either growth or defense mechanisms, such as plant secondary 364 metabolites (e.g. PAs). Over all plants, such a trade-off was significant (Figure 4A, $\mathrm{R}^{2}=0.16$, $P<0.001)$. However, plant yield only explained $16 \%$ of the observed variability in PA leaf concentration and this effect was negligible above $5 \mathrm{~g} \mathrm{DM} \mathrm{plant}^{-1}\left(\mathrm{R}^{2}=0.01\right.$, NS), as seen from

367 the regression line. In addition, within each yield group (e.g. plants of 10-20 g DM), the range 368 in PA concentrations was huge, and a threefold difference in PA concentrations is possible. In 369 conclusion, in the yield range that is of interest for plant breeding (large plants), this trade-off 370 is negligible and a large variability in PA leaf concentration is available that will allow 371 improvement of PA leaf concentrations and yields. 
372 Besides a concomitant increase in PA leaf concentration and yield as discussed above, 373 ameliorating PA composition (at a given concentration of PA) and yield in parallel is a second 374 strategy. The composition of PAs are considered to be at least as important as PA concentration 375 for the bioactivity of PA-containing feeds and their beneficial or antinutritional activity to 376 animal health. ${ }^{7,11}$ Our results on PA composition demonstrate neither a negative relationship 377 (trade-off) between plant yield and $\mathrm{mDP}\left(\mathrm{R}^{2}: 0.01\right.$, NS) nor PD share $\left(\mathrm{R}^{2}: 0.02\right.$, NS) (see 378 supporting information). Accordingly, enhancing the PAs by improving their composition seems possible and should not be hampered by a parallel increase of the forage yield.

\section{Trade-offs: Reduced leaf share with increased plant size}

Another potential trade-off between yield and PA properties is based on the leaf share of the plant. Given the on average 3.5 times higher PA concentration in leaves as compared to stems (Figure 2) the leaf share of the plant becomes an important factor in determining PA concentration of the entire forage $\mathrm{e}^{38,39}$ and studies generally found reduced leaf share in bigger plants. ${ }^{40}$ In fact, Figure 4B shows such a negative correlation (trade-off) between yield and leaf share $\left(\mathrm{R}^{2}=0.66, P<0.001\right)$. However, when observing only plants larger than $20 \mathrm{~g} \mathrm{DM}$, leaf share appears quite stable at about $43 \%$, as can be seen in the regression line (Figure 4B) and no significant effect on leaf share occurred anymore with higher plant weight. In addition, the variability in leaf share was quite large and exhibited a 2-fold variation for three out of four plant size classes (vertical lines, Figure 4B) above $20 \mathrm{~g}$ DM. This indicates that yields could be extensively increased without compromising the leaf share, and that there seems to be enough variability to increase the leaf share at any given plant size. Finally, the possible increments in yield without further reductions in leaf share for plant weights above $20 \mathrm{~g}$ DM are also of importance, as Borreani et al. identified the leaves to be richer in crude protein and lower in

395 Neutral Detergent Fiber (NDF) than the stems (on average 227.7 and $83.3 \mathrm{~g} \mathrm{~kg}^{-1} \mathrm{DM}$ crude 396 protein and 240.0 and $527.7 \mathrm{~g} \mathrm{~kg}^{-1} \mathrm{DM}$ NDF for leaves and stems, respectively). ${ }^{41}$ While 
397 Azuhnwi et al. in a comparison of 15 different sainfoin accessions found significant differences 398 in both crude protein and NDF between these accessions, the range of $156-182 \mathrm{~g} \mathrm{~kg}^{-1} \mathrm{DM}$ for 399 crude protein and 378-417 $\mathrm{g} \mathrm{kg}^{-1}$ DM for NDF, was much lower than the differences between $400 \quad$ leaves and stems. ${ }^{42}$

401 In conclusion, we found that a large variability exists for breeding a sainfoin ideotype with high 402 yields and large amounts of PAs with every possible combination of PD share and mDP, which 403 will be identified to be ideal to obtain high bioactivity. This is of particular importance, as 404 bioactivity is currently the main driver for the cultivation of sainfoin, yet cultivation becomes 405 only attractive once the forage yield is competitive with other forage legumes. Our results 406 suggest three independent strategies to increase bioactivity in the entire forage, which could 407 have an additive effect, if applied together: (1) to ameliorate the composition of PAs, (2) to 408 increase the overall PA concentration in sainfoin organs, and (3) to increase the share of leaves, 409 which are the organs with the highest PA concentration. These findings further strengthen the 410 opportunities offered by sainfoin to ameliorate the sustainability of livestock production. 


\section{Abbreviations used}

412 PAs, Proanthocyanidins; DM, Dry matter; PD, Prodelphinidins; PC, Procyanidins; mDP, Mean

413 Degree of Polymerization; GRH, Growth rate hypothesis; ESI, Electrospray ionization; RSD,

414 Relative standard deviation; maxmDP, largest mDP; GVA, Graphical vector analysis; NDF,

415 Neutral Detergent Fiber

416 Author information

417 Corresponding Author

418 * (A.L.) Phone: +41 58468 7273. E-mail: andreas.luescher@agroscope.admin.ch

$419 \quad$ Funding

420 These investigations were supported by the European Commission (PITN-GA-2011-289377,

421 "LegumePlus" project). Sample analyses by UPLC-MS/MS were made possible by the strategic

422 grant of the University of Turku (Ecological Interactions).

$423 \quad$ Notes

424 The authors declare no competing financial interest.

\section{Acknowledgements}

426 We are very grateful to the USDA ARS-GRIN germplasm database, for the provision of the

427 seeds of the sainfoin accessions. We would like to thank Matthias Suter for his consultancy 428 regarding statistical questions. Furthermore, we would like to thank Hansueli Hirschi, Erich

429 Rosenberg, and Friederike Johnigk for their support with the fieldwork and sample preparation,

430 as well as Maarit Karonen, Anne Koivuniemi, and Jorma Kim for their guidance and assistance

431 in the laboratory. Juuso Laitila helped with the analysis of insoluble tannins. 


\section{Supporting information:}

433

Supporting information contains: List of all examined accessions with their status of cultivation, origin country and ploidy, a visual comparison of different leaf ages, the calculation for the mean degree of Polymerization $(\mathrm{mDP})$ and the largest mean degree of polymerization (maxmDP), the formula for the calculation for amount of proanthocyanidins, a description of the identification of phenolic compounds and the correlation between plant weight and the PD share and between plant weight and the maxmDP. This material is available free of charge via the Internet at http://pubs.acs.org.

\section{References}

(1) Chorley, P., Early Evidence of Sainfoin Cultivation around Paris. Agricultural History Review 1981, 29, 118-124.

(2) Boller, B.; Schubiger, F.X.; Koelliker, R., Red Clover; In Fodder Crops and Amenity Grasses. $1^{\text {st }}$ Edition. Boller, B., Posselt, U. K., Veronesi, F., Eds.; Springer: New York City, New York, 2010; Vol 5, 439-456.

(3) Kingston-Smith, A.H.; Edwards, J.E.; Huws, S.A.; Kim, E.J.; Abberton, M., Plant-based strategies towards minimising 'livestock's long shadow'. Proceedings of the Nutrition Society 2010, 69, 613-620.

(4) Lüscher, A.; Mueller-Harvey, I.; Soussana, J.F.; Rees, R.M.; Peyraud, J.L., Potential of legumebased grassland-livestock systems in Europe: a review. Grass and Forage Science 2014, 69, 206-228.

(5) Wang, Y.; McAllister, T.A.; Acharya, S., Condensed Tannins in Sainfoin: Composition, Concentration, and Effects on Nutritive and Feeding Value of Sainfoin Forage. Crop Science 2015, 55, 13-22.

(6) Aufrere, J.; Dudilieu, M.; Andueza, D.; Poncet, C.; Baumont, R., Mixing sainfoin and lucerne to improve the feed value of legumes fed to sheep by the effect of condensed tannins. Animal 2013, 7 , $82-92$.

(7) Mueller-Harvey, I., Unravelling the conundrum of tannins in animal nutrition and health. Journal of the Science of Food and Agriculture 2006, 86, 2010-2037.

(8) Scharenberg, A.; Arrigo, Y.; Gutzwiller, A.; Soliva, C.R.; Wyss, U.; Kreuzer, M.; Dohme, F., Palatability in sheep and in vitro nutritional value of dried and ensiled sainfoin (Onobrychis viciifolia) birdsfoot trefoil (Lotus corniculatus), and chicory (Cichorium intybus). Archives of Animal Nutrition 2007, 61, 481-496.

(9) Kommuru, D.S.; Barker, T.; Desai, S.; Burke, J.M.; Ramsay, A.; Mueller-Harvey, I.; Miller, J.E.; Mosjidis, J.A.; Kamisetti, N.; Terrill, T.H., Use of pelleted sericea lespedeza (Lespedeza cuneata) for natural control of coccidia and gastrointestinal nematodes in weaned goats. Veterinary Parasitology 2014, 204, 191-198.

(10) Mechineni, A.; Kommuru, D.S.; Gujja, S.; Mosjidis, J.A.; Miller, J.E.; Burke, J.M.; Ramsay, A.; Mueller-Harvey, I.; Kannan, G.; Lee, J.H., et al., Effect of fall-grazed sericea lespedeza (Lespedeza cuneata) on gastrointestinal nematode infections of growing goats. Veterinary Parasitology 2014, 204, 221-228.

(11) Hatew, B.; Stringano, E.; Mueller-Harvey, I.; Hendriks, W.H.; Carbonero, C.H.; Smith, L.M.J.; Pellikaan, W.F., Impact of variation in structure of condensed tannins from sainfoin (Onobrychis viciifolia) on in vitro ruminal methane production and fermentation characteristics. Journal of Animal 
Physiology and Animal Nutrition. [Online early access]. doi: 10.1111/jpn.12336. Published Online: May $8^{\text {th }}, 2015$. (accessed: September $30^{\text {th }}, 2015$ ).

(12) Huang, X.D.; Liang, J.B.; Tan, H.Y.; Yahya, R.; Long, R.; Ho, Y.W., Protein-binding affinity of leucaena condensed tannins of differing molecular weights. Journal of Agricultural and Food Chemistry 2011, 59, 10677-10682.

(13) Zeller, W.E.; Sullivan, M.L.; Mueller-Harvey, I.; Grabber, J.H.; Ramsay, A.; Drake, C.; Brown, R.H., Protein Precipitation Behavior of Condensed Tannins from Lotus pedunculatus and Trifolium repens with Different Mean Degrees of Polymerization. Journal of Agricultural and Food Chemistry 2015, 63, 1160-1168.

(14) Barrau, E.; Fabre, N.; Fouraste, I.; Hoste, H., Effect of bioactive compounds from sainfoin (Onobrychis viciifolia Scop.) on the in vitro larval migration of Haemonchus contortus: role of tannins and flavonol glycosides. Parasitology 2005, 131, 531-538.

(15) Klongsiriwet, C.; Quijada, J.; Williams, A.R.; Mueller-Harvey, I.; Williamson, E.M.; Hoste, H., Synergistic inhibition of Haemonchus contortus exsheathment by flavonoid monomers and condensed tannins. International Journal for Parasitology: Drugs and Drug Resistance 2015, 5, 127-134.

(16) Lattanzio, V., Bioactive polyphenols: Their role in quality and storability of fruit and vegetables. Journal of Applied Botany 2003, 77, 128-146.

(17) Scioneaux, A.; Schmidt, M.; Moore, M.; Lindroth, R.; Wooley, S.; Hagerman, A., Qualitative variation in proanthocyanidin composition of populus species and hybrids: genetics is the key. Journal of Chemical Ecology 2011, 37, 57-70.

(18) Regos, I.; Urbanella, A.; Treutter, D., Identification and quantification of phenolic compounds from the forage legume sainfoin (Onobrychis viciifolia). Journal of Agricultural and Food Chemistry 2009, 57, 5843-5852.

(19) Engström, M.T.; Pälijärvi, M.; Fryganas, C.; Grabber, J.H.; Mueller-Harvey, I.; Salminen, J.-P., Rapid qualitative and quantitative analyses of proanthocyanidin oligomers and polymers by UPLCMS/MS. Journal of Agricultural and Food Chemistry 2014, 62, 3390-3399.

(20) Salminen, J.-P., Effects of sample drying and storage, and choice of extraction solvent and analysis method on the yield of birch leaf hydrolyzable tannins. Journal of Chemical Ecology 2003, 29, 1289-1305.

(21) Baert, N.; Karonen, M.; Salminen, J.-P., Isolation, characterisation and quantification of the main oligomeric macrocyclic ellagitannins in Epilobium angustifolium by ultra-high performance chromatography with diode array detection and electrospray tandem mass spectrometry. Journal of Chromatography A., [Online early access]. doi:10.1016/j.chroma.2015.09.050. Published Online: September 21 ${ }^{\text {st }}$, 2015. http://www.sciencedirect.com/science/article/pii/S0021967315013564 (accessed September $30^{\text {th }}, 2015$ ).

(22) Boller, B.; Greene, S., Genetic Resources. In Fodder Crops and Amenity Grasses. $1^{\text {st }}$ Edition. Boller, B., Posselt, U. K., Veronesi, F., Eds.; Springer: New York City, New York, 2010; Vol. 5, 13-38. (23) Pinheiro, J.; Bates, D.; DebRoy, S.; Sarkar, D.; R Core Team. nlme: linear and nonlinear mixed effects models, R package version 3.1-117; 2014.

(24) R Core Team R: A language and environment for statistical computing, Vienna, Austria, 2014. (25) Figueroa-Pérez, M.G.; Rocha-Guzmán, N.E.; Pérez-Ramírez, I.F.; Mercado-Silva, E.; ReynosoCamacho, R., Metabolite profile, antioxidant capacity, and inhibition of digestive enzymes in infusions of peppermint (Mentha piperita) grown under drought stress. Journal of Agricultural and Food Chemistry 2014, 62, 12027-12033.

(26) Goplen, B.P.; Richards, K.W.; Moyer, J.R., Sainfoin for western Canada. $3^{\text {rd }}$ Edition. Agriculture Canada: Ottawa, Canada, 1991; 1-22.

(27) Walter, A.; Studer, B.; Kölliker, R., Advanced phenotyping offers opportunities for improved breeding of forage and turf species. Annals of Botany 2012, 110, 1271-1279.

(28) Council of the European Union, Council Directive 2002/53/EC of 13 June 2002 on the common catalogue of varieties of agricultural plant species. In Official Journal 2002; Vol. L 193, 0001 - 0011.

(29) Theodoridou, K.; Aufrere, J.; Andueza, D.; Le Morvan, A.; Picard, F.; Stringano, E.; Pourrat, J.; Mueller-Harvey, I.; Baumont, R., Effect of plant development during first and second growth cycle on chemical composition, condensed tannins and nutritive value of three sainfoin (Onobrychis viciifolia) varieties and lucerne. Grass and Forage Science 2011, 66, 402-414. 
528 (30) Stringano, E.; Carbonero, C.H.; Smith, L.M.J.; Brown, R.H.; Mueller-Harvey, I., 529 Proanthocyanidin diversity in the EU 'HealthyHay' sainfoin (Onobrychis viciifolia) germplasm collection. Phytochemistry 2012, 77, 197-208.

(31) Lee, C.-C.; Shen, S.-R.; Lai, Y.-J.; Wu, S.-C., Rutin and quercetin, bioactive compounds from tartary buckwheat, prevent liver inflammatory injury. Food \& Function 2013, 4, 794-802.

(32) Koricheva, J., Interpreting phenotypic variation in plant allelochemistry: problems with the use of concentrations. Oecologia 1999, 119, 467-473.

(33) Salminen, J.-P.; Ossipov, V.; Pihlaja, K., Distribution of hydrolysable tannins in the foliage of Finnish birch species. In Zeitschrift für Naturforschung C, 2002; 57, 248-256.

(34) Grabber, J.H.; Zeller, W.E.; Mueller-Harvey, I., Acetone enhances the direct analysis of procyanidin- and prodelphinidin-based condensed tannins in lotus species by the butanol-HCl-iron assay. Journal of Agricultural and Food Chemistry 2013, 61, 2669-2678.

(35) Lees, G.L.; Gruber, M.Y.; Suttill, N.H., Condensed tannins in sainfoin .2. occurrence and changes during leaf development. Canadian Journal of Botany-Revue Canadienne De Botanique 1995, $73,1540-1547$.

(36) Coley, P.D.; Bryant, J.P.; Chapin, F.S., Resource availability and plant antiherbivore defense. Science 1985, 230, 895-899.

(37) Nancy Stamp, Out of the quagmire of plant defense hypotheses. The Quarterly Review of Biology 2003, 78, 23-55.

(38) Häring, D.A.; Scharenberg, A.; Heckendorn, F.; Dohme, F.; Luscher, A.; Maurer, V.; Suter, D.; Hertzberg, H., Tanniferous forage plants: agronomic performance, palatability and efficacy against parasitic nematodes in sheep. Renewable Agriculture and Food Systems 2008, 23, 19-29.

(39) Haring, D.A.; Suter, D.; Amrhein, N.; Lushcer, A., Biomass allocation is an important determinant of the tannin concentration in growing plants. Annals of Botany 2007, 99, 111-120.

(40) Lemaire, G.; Gastal, F., N uptake and distribution in plant canopies. In Diagnosis of the Nitrogen Status in Crops; Lemaire, G., Ed. Springer Berlin Heidelberg: 1997; 3-43.

(41) Borreani, G.; Peiretti, P.G.; Tabacco, E., Evolution of yield and quality of sainfoin (Onobrychis viciifolia Scop.) in the spring growth cycle. Agronomie 2003, 23, 193-201.

(42) Azuhnwi, B.N.; Boller, B.; Martens, M.; Dohme-Meier, F.; Ampuero, S.; Gunter, S.; Kreuzer, M.; Hess, H.D., Morphology, tannin concentration and forage value of 15 Swiss accessions of sainfoin (Onobrychis viciifolia Scop.) as influenced by harvest time and cultivation site. Grass and Forage Science 2011, 66, 474-487.

(43) Veitch, N.C.; Regos, I.; Kite, G.C.; Treutter, D., Acylated flavonol glycosides from the forage legume, Onobrychis viciifolia (sainfoin). Phytochemistry 2011, 72, 423-429.

(44) Marais, J.P.J.; Mueller-Harvey, I.; Brandt, E.V.; Ferreira, D., Polyphenols, condensed tannins, and other natural products in Onobrychis viciifolia (Sainfoin). Journal of Agricultural and Food Chemistry 2000, 48, 3440-3447.

(45) Lu, Y.R.; Sun, Y.; Foo, L.Y.; McNabb, W.C.; Molan, A.L., Phenolic glycosides of forage 566 legume Onobrychis viciifolia. Phytochemistry 2000, 55, 67-75. 
568 Figure 1: A) Proanthocyanidin concentration [PA] in leaves, B) mean degree of 569 polymerization (mDP), C) share of prodelphinidins (PD), and D) the plant weight of 570 sainfoin accessions, arranged in order of their status of cultivation and - within status 571 increasing plant weight.

572 Displayed are predicted means and population standard deviations of each accession based on 573 regression analysis (eqs 1 \& 2). Different letters among group values indicate significant 574 differences at $P \leq 0.05$ : upper case for group means (eqn 1), lower case for standard deviations 575 (eqn 2). Note the log-scale in panels C) and D). Accession NA/RCAT028437 is abbreviated as 576 RCAT and Cholderton-Hampshire Common as Hampshire.

577 Figure 2: A) Proanthocyanidin concentration [PA], B) mean degree of polymerization 578 (mDP), C) maximum degree of polymerization (maxmDP), D) share of prodelphinidins 579 (PD), E) quercetin- $O$-rutinoside concentration, and F) nicotiflorin concentration in leaves 580 of different ages and stems.

581 Boxes display medians (bold line), the first and third quartile (lower and upper line of box), and 582 whiskers extending to the most extreme data point, which is less than 1.5 times of the 583 interquartile range. Different letters among medians indicate significant differences at $P \leq 0.05$.

584 Figure 3: Graphical vector analysis for leaves of sainfoin (Onobrychis viciifolia), 585 comparing the concentration and amount of proanthocyanidins (PA).

586 Arrows follow aging of leaves from young to intermediate aged leaves, and from there to old 587 leaves. Grey dotted lines are isolines for leaf biomass; arrows crossing the lines indicate 588 changes in biomass. Synthesis rate changes are defined by angle relative to biomass isolines 589 and can be identified with the help of the black arrows on the top right. Error bars indicate 590 standard error. 
591 Figure 4: A) Proanthocyanidin concentration [PA] in leaves, and B) leaf share of 592 individual plants both compared to plant yield.

593 Data are for the first harvests of the years 2013 and 2014. The equation for the exponential 594 trendline and its regression analysis are denoted at the bottom right.

595 


\section{Tables}


Table 1: Chromatographic, UV, and mass spectral characteristics of individual phenolic compounds identified in the sainfoin extract ${ }^{1}$.

\begin{tabular}{|c|c|c|c|c|c|c|c|c|}
\hline Comp. & $\mathbf{R}_{\mathbf{T}}$ & {$[\mathbf{M}-\mathbf{H}]^{-}$} & $\mathbf{M S}^{2}$ & Fragments of daughter ion & $\lambda_{\max }$ & Tentative ID & MRM & RSD \\
\hline 1 & 1.18 & 271 & 108 & & 222,282 & Arbutin $^{\mathrm{a}, \mathrm{b}}$ & & 6.5 \\
\hline 2 & 2.01 & 331 & 169 & & 222,272 & 1-O-Monogalloylglucose $\mathrm{a}^{\mathrm{a}}$ & $331>169$ & 2.9 \\
\hline 3 & 2.44 & 353 & $\underline{191}, 179,135$ & 108 & 219,323 & Caffeoylquinic acid ${ }^{\mathrm{b}}$ & $353>191$ & 3.5 \\
\hline 4 & 2.87 & 353 & $\underline{191}$ & $171,155,137,115,108$ & 244,324 & Chlorogenic acid ${ }^{\mathrm{a}, \mathrm{b}}$ & $353>191$ & 2.5 \\
\hline 5 & 2.92 & 325 & $\underline{163}, 119$ & 119 & ND & Coumaric acid glucoside $e^{b, e}$ & & \\
\hline 6 & 2.92 & 625 & $\underline{463}, 301,299$ & 301 & 255,352 & Quercetindihexoside & $625>300$ & \\
\hline 7 & 3.32 & 337 & $\underline{191}, 173,163,119$ & $173,127,111$ & 230,310 & Coumaroylquinic acid ${ }^{\mathrm{b}, \mathrm{e}}$ & $337>191$ & \\
\hline 8 & 3.65 & 337 & $\underline{191}, 173,163,127,119$ & $173,137,127,111$ & 234,304 & Coumaroylquinic acid ${ }^{\mathrm{b}, \mathrm{e}}$ & $337>191$ & \\
\hline 9 & 3.68 & 325 & $163, \underline{119}$ & 117,101 & 219,279 & Coumaric acid glucoside $\mathrm{e}^{\mathrm{b}, \mathrm{e}}$ & & 4.2 \\
\hline 10 & 2.93 & 771 & $\underline{609}, 462,301$ & $300,272,194$ & 255,352 & Quercetin-3-O-rutinoside-7- $O-\beta-\mathrm{D}$-glucoside ${ }^{\mathrm{e}}$ & & 3.9 \\
\hline 11 & 3.56 & 755 & 301 & & 255,352 & Quercetin-3-O-rhamnosylrutinoside ${ }^{\mathrm{b}, \mathrm{d}, \mathrm{e}}$ & & 1.4 \\
\hline 12 & 3.79 & 739 & 285,284 & & 265,347 & Kaempferol-3-O-rhamnosylrutinoside ${ }^{\mathrm{b}, \mathrm{e}}$ & & 1.4 \\
\hline 13 & 3.89 & 609 & $301,300,271,255$ & & 255,352 & Quercetin-3-O-rutinoside ${ }^{\mathrm{a}, \mathrm{b}, \mathrm{e}}$ & $609>300$ & 2.2 \\
\hline 14 & 4.20 & 593 & 285 & & 265,346 & Kaempferol-3-O-rutinoside ${ }^{\mathrm{a}, \mathrm{b}, \mathrm{e}}$ & $593>285$ & 0.8 \\
\hline 15 & 4.24 & 505 & 301 & & 254,351 & Quercetinacetylhexoside & & \\
\hline 16 & 4.28 & 623 & 315,300 & & 254,352 & Isorhamnetin-3-O-rutinoside ${ }^{\mathrm{b}}$ & & \\
\hline 17 & 4.62 & 489 & $285,284,255,227$ & & 265,335 & Kaempferolacetylhexoside & & \\
\hline 18 & 3.55 & 625 & 316,271 & & 258,355 & Myricetin-3-O-rutinoside ${ }^{\mathrm{b}, \mathrm{e}}$ & & 2.0 \\
\hline
\end{tabular}




$\begin{array}{llcc}20 & 3.94 & 463 & 317,316,287,271,179,151 \\ 21 & 4.02 & 463 & 301,300,271,255,179,151 \\ 22 & 4.33 & 447 & 285,255,227 \\ 23 & 5.10 & 961 & \underline{755}, 301,300,179\end{array}$

24

$5.12 \quad 931 \quad \underline{755}, 301,300$

228,349
255,353
265,348
243,335

Myricetin-3-O-rhamnoside ${ }^{\mathrm{a}, \mathrm{b}}$

Quercetin 3-O-(4"'-O-E-sinapoyl)- $\alpha$ -

rhamnopyranosyl-(1"' $\left.\rightarrow 2^{\prime \prime}\right)$ [ $\alpha$-rhamnopyranosyl-

$$
\left.\left(1^{\prime \prime} " \rightarrow 6^{\prime \prime}\right)\right]-\beta \text {-glucopyranoside }{ }^{c}
$$

243, 334

rhamnopyranosyl-(1"' $\left.\rightarrow 2^{\prime \prime}\right)[\alpha-$-rhamnopyranosyl-

$\left.\left(1^{\prime \prime} " \rightarrow 6^{\prime \prime}\right)\right]-\beta$-glucopyranoside ${ }^{c}$

${ }^{1}$ RSD is the relative standard deviation of a replicate quantitative analysis of all the main compounds included in the quantifications. Oligomeric and polymeric proanthocyanidins are not shown in the table since they do not elute as sharp chromatographic peaks. They were identified and quantified by MS/MS according to Engström et al. (2014)

a identification compared to a reference standard

${ }^{\mathrm{b}}$ as previously identified by Regos et al. (2009) ${ }^{18}$

${ }^{c}$ as previously identified by Veitch et al. (2011) ${ }^{43}$

${ }^{d}$ as previously identified by Marais et al. (2000) ${ }^{44}$

${ }^{\text {e }}$ as previously identified by Lu et al. (2000) ${ }^{45}$ 


\section{Figures}

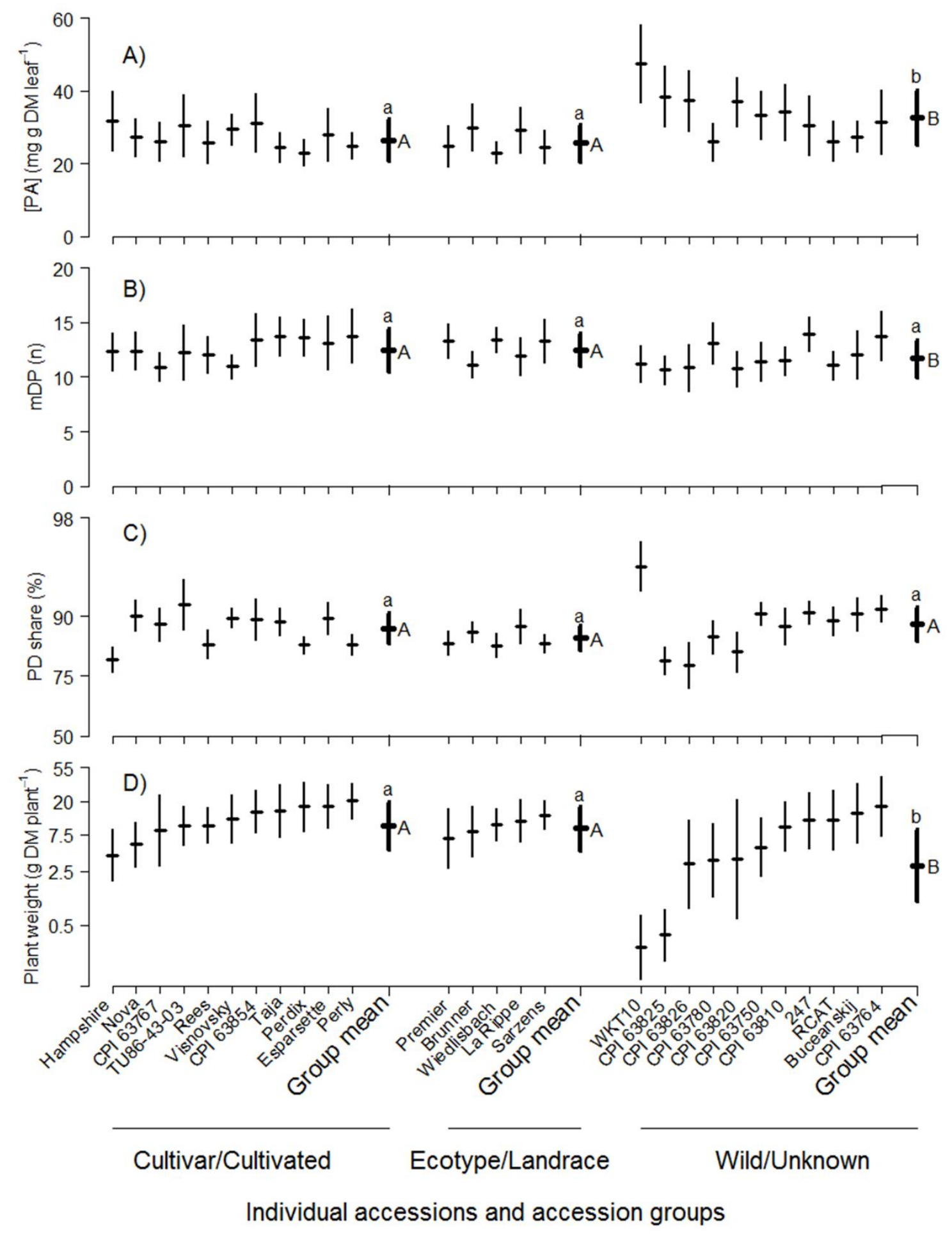

Figure 1 

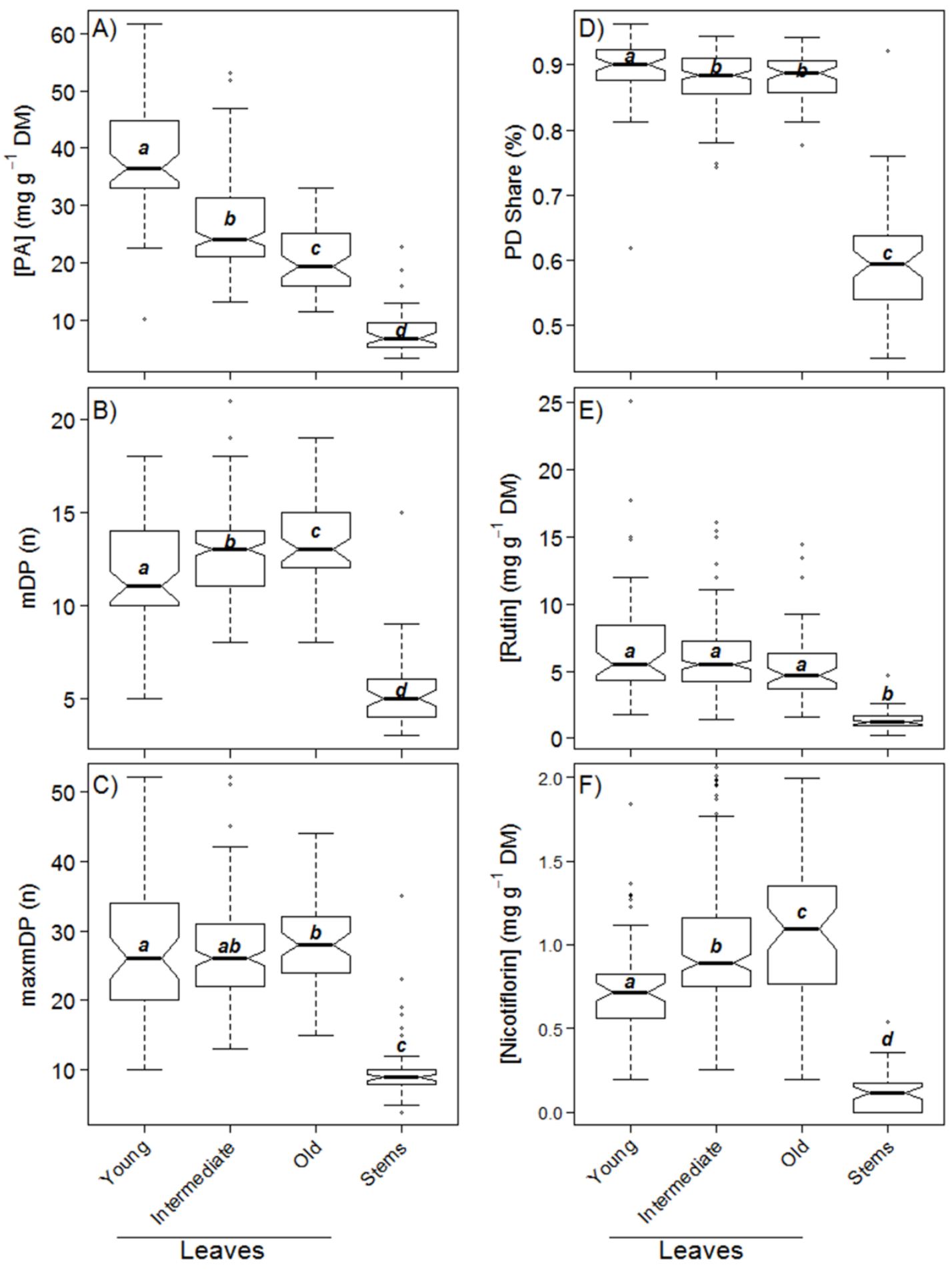

Figure 2 


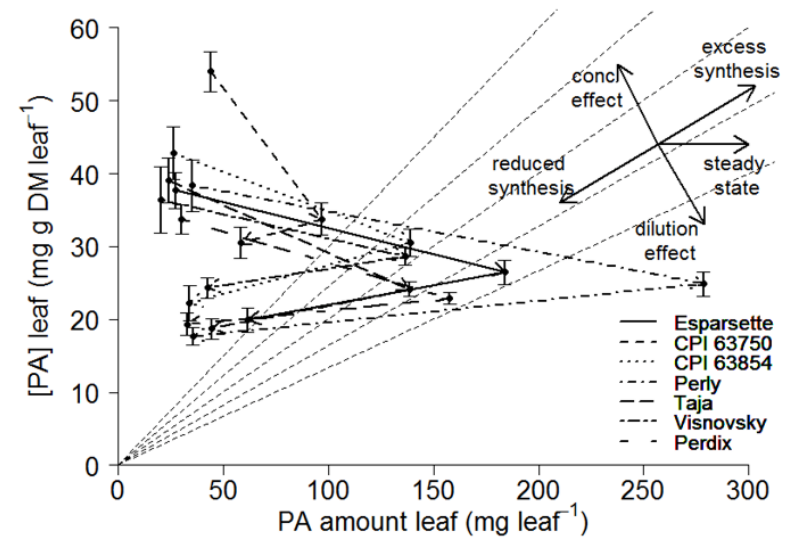

Figure 3 


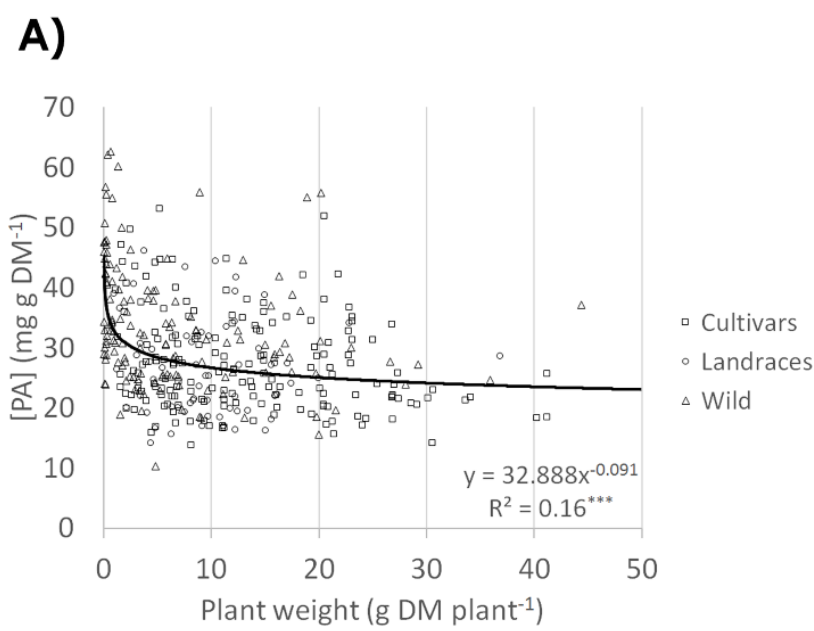

B)

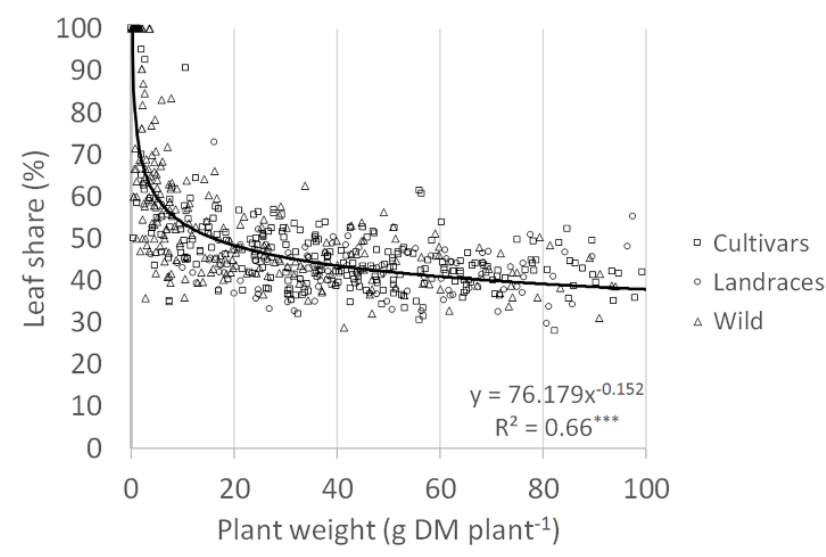

Figure 4 
Graphic for table of contents

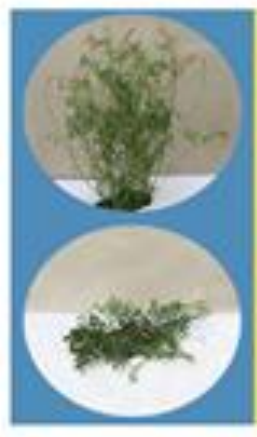

Yield

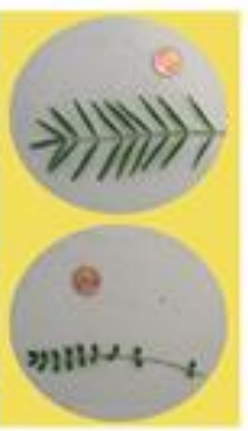

Leafiness
Agronomic and chemical variability in sainfoin

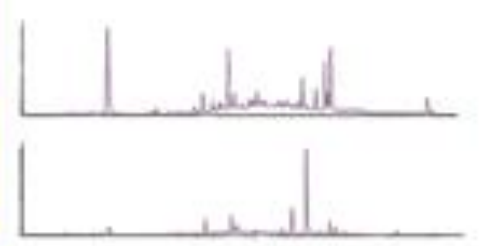

UPLC-chromatogram 